Pathophysiology

of Haemostasis and Thrombosis

\title{
Clinical use of novel antithrombotic agents in the management of acute coronary syndromes
}

\author{
Giovanni Melandri, Pierluigi Tricoci, Chiara Melloni, Samuele Nanni, Franco Semprini, \\ Francesco Fallani, Angelo Branzi
}

Institute of Cardiology, Bologna University

\section{Key Words}

Acute coronary syndromes

Antithrombotic treatment

Thrombosis

\begin{abstract}
Among patients with ST elevation-acute coronary syndrome (ACS) novel thrombolytic agents can be given as a bolus (reteplase, tenecteplase) and their delivery is easier and may shorten the time to treatment, providing the ideal tool in the pre-hospital setting.

Reinfarction after thrombolysis occurs in the 3-5\% range in all major trials. Reinfarction after thrombolysis rate may be reduced by abciximab and enoxaparin. However major hemorrhage is doubled by abciximab (but not by enoxaparin).

When primary angioplasty is preferred to thrombolysis, adjunctive abciximab decreases the need for urgent target vessel revascularization.

A whole body of literature tells that aspirin is not enough in patients without ST elevation ACS. Most patients benefit from concomitant clopidogrel. High-risk patients are candidate to the use GP Ilb-IIIA blockers, particularly if they need coronary angioplasty.

All patients with glomerular filtration rate $\geq 30 \mathrm{ml} / \mathrm{min}$
\end{abstract}

should receive low molecular weight heparin. Evidence for that is mainly driven by studies using enoxaparin.

Copyright (C) 2002 S. Karger AG. Basel

Great emphasis has been placed on the role of antithrombotic therapy in acute coronary syndromes over the last fifteen years, following the observation that coronary thrombosis is the usual precipitating factor $[1,2]$. As a result, the scientific community has witnessed an impressive escalation of trials with countless recruits, showing a progressively important role of anti-thrombotic drugs covering the whole spectrum of the disease, from its onset (pre-hospital) to the long-term followup.

Some manoeuvres are now so deeply-rooted(aspirin, thrombolytic therapy, thienopyridines after coronary stent implantation) that their use is taken as an indicator of quality treatment provided by health care systems [3]. Other antithrombotic drugs of proven efficacy lag behind (warfarin, direct thrombin inhibitors) mainly for the perception of their low benefit-to-risk ratio profile. Other drugs are used only in a fraction of patients (parenteral glycoprotein IIB-IIIA inhibitors) or have dramatically failed (oral glycoprotein IIBIIIA inhibitors).

Despite the above ups and downs the "mobile average" is toward a progressive increase in the use of antithrombotic agents, with the term "increase" referring to the number of drugs being combined in the single patient, the duration of

\section{KARGER \\ () 2002 S. Karger AG. Base \\ $1424-8832 / 02 / 0326-0282 \$ 18.50 / 0$}

Fax +41613061234
Giovanni Melandri, MD, FESC

Istituto di Cardiologia

Policlinico S.Orsola

Via Massarenti, 9 - 40138 Bologna, Italy

tel: ++39(0) 516363434 - fax: ++39(0) 51344859

E-Mail: gmelandri@orsola-malpighi.med.unibo.it 
treatment, the identification of high-risk categories, the number-vs-intensity of treatment(s) issues and the like.

At the same time, hazards of antithrombotic treatments are increasingly scrutinized and are of major importance when it comes to the clinical use setting.

From a practical point of view acute coronary syndromes are divided among those patients showing persistent ST segment elevation in their presenting electrocardiogram and those without persistent ST elevation.

\section{Acute coronary syndromes with persistent ST segment elevation}

Thrombolytic therapy is the key treatment of patients with persistent ST segment elevation. The quick delivery of a lytic drug has been shown to save lives practically in almost all subgroups of patients admitted within 12 hours from symptoms onset [4]. One distinct feature of thrombolytic therapy is the strict inverse relationship between delay of treatment and capacity to reduce in-hospital and long-term mortality. The socalled "golden hour" identifies a subgroup of patients for whom thrombolytic therapy (delivered within 1 hour from the onset of symptoms) may save as many as 65 lives per 1000 treated patients [5].

The importance of time to treatment cannot be overemphasized because it has been confirmed in many ways and under different circumstances. Thus, it has been shown that the prehospital administration of thrombolysis reduces total mortality compared to in-hospital treatment [6], a performance that parallels that of primary angioplasty [7]. Actually, similar outcomes have been reported when prehospital thrombolysis and primary angioplasty have been compared directly [8].
The availability of new thrombolytic agents (reteplase, tenecteplase) that can be safely administered as a bolus not only decreases medication errors [9], but also speeds up drug delivery, allowing treatment in the emergency department environment [10]. Nurse-initiated thrombolysis is a distinct option being tested in the field [11] and further expands the room for implementing reperfusion in as many patients as possible.

Although logistics appear the main advantage of new thrombolytic agents, different pharmacologic profiles may result in selective clinical advantages. In the ASSENT-2 study the equivalence of tenecteplase and alteplase on mortality was nicely shown (6.18 vs $6.15 \%, \mathrm{p}=\mathrm{NS})$; however the need for blood transfusions was lower in the group receiving tenecteplase (4.25 vs $5.49 \%, \mathrm{p}=0.0002)$ [12]. Particularly female patients at high risk for bleeding ( $>75$ years old and body weight $<67 \mathrm{~kg}$ ) take advantage from the treatment [13]. Again, in the ASSENT-2 study it was shown that time-to treatment not only determines clinical outcomes but also the referfusion efficacy itself [14], suggesting that fibrin cross-linking proceeds very quickly in the early phase of coronary thrombosis. Thus, not only "time-is-muscle" (being lost) but probably also "time is thrombus" (being accrued).

The Achille's heel of thrombolysis is re-occlusion. Lysis and reocclusion take place simultaneously from the beginning and the net effect determines the ultimate patency.

Therefore, thrombolytic drugs need some form of adjunctive treatment. Aspirin is a must after the ISIS-2 trial [15]. Intravenous heparin is used with fibrin-specific lytic agents, although the evidence for heparin use is weak. The principal reason for using unfractionated heparin in combination with fibrin-specific drugs is that this combination was successful in reducing the mortality rate compared to streptokinase in the

Table 1. Novel adjunctive treatments in combination with thrombolysis in the ASSENT-3 Study 18

\begin{tabular}{lccc}
\hline OUTCOME & $\begin{array}{c}\text { UNFRACTIONATED } \\
\text { HEPARIN } \\
(\mathrm{N}=2038)\end{array}$ & $\begin{array}{c}\text { ENOXAPARIN } \\
(\mathrm{N}=2040)\end{array}$ & $\begin{array}{c}\text { ABCIXIMAB } \\
(\mathrm{N}=2017)\end{array}$ \\
\hline 30-day death / in-hospital & $15.4 \%$ & $11.4 \%$ & $11.1 \%$ \\
reinfarction / refractory ischemia * & $17.0 \%$ & $13.8 \%$ & $14.2 \%$ \\
30-day death / in-hospital reinfarction / & $6.0 \%$ & $5.4 \%$ & $6.6 \%$ \\
refractory ischemia / ICH / major bleed ** & $4.2 \%$ & $2.7 \%$ & $2.2 \%$ \\
30-day death *** & $6.5 \%$ & $4.6 \%$ & $3.2 \%$ \\
In-hospital reinfarction **** & $0.9 \%$ & $0.9 \%$ & $0.9 \%$ \\
In-hospital refractory ischemia * & $2.2 \%$ & $3.0 \%$ & $4.3 \%$ \\
In-hospital ICH *** & & & \\
Major bleeds (other than ICH) $* * * * *$ & & & \\
\hline
\end{tabular}

$\begin{array}{ll}\text { ICH: intracranial haemorrhage } \\ * * * & \mathrm{p}=0.0001 \\ * * & \mathrm{p}=0.0081 \\ * * * & \mathrm{p}=\mathrm{NS} \\ * * * * & \mathrm{p}=0.0009 \\ * * * * * & \mathrm{p}=0.0005\end{array}$


Table 2. Trials on the use of glycoprotein IIB-IIIA blockers in conjunction with primary angioplasty 21.

\begin{tabular}{|c|c|c|c|c|}
\hline $\begin{array}{l}\text { STUDY } \\
\text { (No Patients) }\end{array}$ & $\begin{array}{l}\text { PRIMARY } \\
\text { END-POINT }\end{array}$ & АВСIXIMAВ & PLACEBO & $\mathbf{P}$ \\
\hline ADMIRAL (300) 41 & D / RI / UTVR * & $6.0 \%$ & $14.6 \%$ & 0.01 \\
\hline RAPPORT (483) 42 & D / RI / TVR ** & $28.2 \%$ & $28.1 \%$ & NS \\
\hline ISAR-2 (292) 43 & LUMEN LOSS $* * *$ & $1.26 \pm 0.85 \mathrm{~mm}$ & $1.21 \pm 0.74 \mathrm{~mm}$ & NS \\
\hline CADILLAC (2082) 44 & D / RI / DS / IDTVR ** & $15.8 \%$ & $13.4 \%$ & NS \\
\hline
\end{tabular}

D : death ; DS : disabling stroke; IDTVR: Ischemia-driven target-vessel-revascularization; RI: recurrent infarction; (U)TVR: (urgent) target vessel revascularization

* at 30 days

** at 6 months

*** angiography at 6 months; binary restenosis rate $31.1 \mathrm{vs} 30.6 \%$

GUSTO-I study [16]. Despite these achievements intravenous heparin therapy is affected by many drawbacks: poor anticoagulation control, particularly in the first 12 hours after thrombolytic therapy, a very narrow therapeutic index and the absolute need for the tight adherence to well-established infusion nomograms, based on careful monitoring of the aPTT level.

Unlike unfractionated heparin, low molecular weight heparins have more predictable kinetics, are less proteinbound, have less potential for platelet activation and do not require monitoring. Several mechanistic studies have shown the capacity of low molecular weight heparins to decrease coronary reocclusion or to increase late patency after thrombolysis; interestingly, this effect has been shown to occur even when the thrombolytic agent is not fibrin-specific (streptokinase) [17], contradicting the widespread opinion that an anticoagulant is not needed when there is a lytic state. Recently the ASSENT-3 investigators confirmed in a several-thousand patients trial that enoxaparin, compared to unfractionated heparin, is able to improve in-hospital prognosis of patients receiving tenecteplase (Table 1) [18]. Thus, enoxaparin opens a new way in the reperfusion treatment of acute myocardial infarction, for the first time allowing to reduce recurrent inhospital infarction after thrombolysis, an achievement so far obtained mainly by primary angioplasty [7]. Ongoing trials are evaluating the capacity of enoxaparin to reduce 30-day reinfacrtion as well as other adverse outcomes in a more general way, including several different thrombolytic agents.

Recurrent infarction after thrombolysis may also be curbed by the adjunctive infusion of glycoprotein IIB-IIIA receptor antagonists. However this combination resulted in major haemorrhage excess not only in the ASSENT-3 trial (Table 1), but also in the large GUSTO-V study [ 19 ]. Particularly those patients more than 75 years-old experienced almost a doubling of intracranial haemorrhage following the infusion of abciximab combined with half-dose thrombolytic agent. The bleeding excess was also confirmed in the INTRO-AMI study, evaluating the combination of alteplase with eptifibatide [20]. For these reasons the combination of a lytic drug with a glycopro- tein IIB-IIIA blocker is not presently recommended by the European guideline on management of patients with persistent ST segment elevation [21].

The use of abciximab in the context of primary angioplasty is recommended by the European guideline (Class I when stenting is not used, Class IIa with stent implantation) [21] (table 2).

\section{Acute coronary syndromes without persistent ST segment elevation}

These syndromes encompass a whole spectrum of clinical situations with different clinical risk. They range from a lowrisk population for which early discharge after the observation for 12 hours in a chest pain unit is feasible, to very high-risk patients with ongoing Ischemia, hemodynamic compromise, malignant arrhythmias for whom an aggressive strategy of revascularization is needed. The basic tenet is the occurrence of a mural coronary thrombus (or alternatively of an occlusive thrombus in a collateralised vessel). Consequences are strictly dependent on vessel size, concomitant other coronary obstructions, collaterals development, the degree of myocardial damage and the residual left ventricular pump function. Other important covariates affecting risk are: age, diabetes mellitus, previous vascular events, prior aspirin use, renal insufficiency, the occurrence of ST segment depression in the electrocardiogram, the positivity in the troponin assay and left ventricular ejection fraction [22-24].

Although aspirin is the mainstay of antithrombotic therapy of all types of acute coronary syndrome, evidence is mounting that aspirin alone "is not enough". Most subgroups, also including low-risk categories, take advantage of the concomitant use of clopidogrel. In the CURE study the intention to treat for 1 year with the combination of aspirin plus clopidogrel resulted in the $20 \%$ reduction in the composite of death, non-fatal myocardial infarction and stroke $(\mathrm{p}<0.0001)$ [25]. The recent European guideline on management of non-ST segment elevation acute coronary syndromes places clopidogrel 
Table 3. Rate of death / non-fatal myocardial infarction in trials of glycoprotein IIB-IIIA receptor blockers in acute coronary syndromes without persistent ST segment elevation 44

\begin{tabular}{llll}
\hline TRIAL (drug) & $\begin{array}{l}\text { ACTIVE } \\
\text { GROUP }\end{array}$ & $\begin{array}{l}\text { CONTROL } \\
\text { GROUP }\end{array}$ & $\begin{array}{l}\text { OR } \\
(\mathbf{9 5} \% \text { CI })\end{array}$ \\
\hline PRISM (tirofiban) 46 & $5.8 \%$ & $7.1 \%$ & $0.80(0.60-1.06)$ \\
PRISM-PLUS (tirofiban) 47 & $8.7 \%$ & $11.9 \%$ & $0.70(0.50-0.98)$ \\
PARAGON-A (lamifiban) 48 & $11.6 \%$ & $11.7 \%$ & $0.99(0.68-1.44)$ \\
PURSUIT (eptifibatide) 49 & $14.2 \%$ & $15.7 \%$ & $0.89(0.79-1.00)$ \\
PARAGON-B (lamifiban) 50 & $10.6 \%$ & $11.5 \%$ & $0.92(0.77-1.09)$ \\
GUSTO-IV-ACS (abciximab) 51 & $8.2 \% *$ & $8.0 \%$ & $1.02(0.83-1.24) *$ \\
OVERALL & $9.1 \% * *$ & & $1.15(0.94-1.39) * *$ \\
\hline
\end{tabular}

* Abciximab infusion: 24 hours

** Abciximab infusion: 48 hours

Table 4. Short-term rate of death / non-fatal myocardial infarction in trials of low molecular weight heparins in acute coronary syndromes without persistent ST segment elevation

\begin{tabular}{lllll}
\hline $\begin{array}{l}\text { STUDY } \\
\text { (DRUG) }\end{array}$ & $\begin{array}{l}\text { TIMING OF THE } \\
\text { END-POINT }\end{array}$ & LMWH & UFH & $\begin{array}{l}\text { OR } \\
(95 \% \text { CI })\end{array}$ \\
\hline FRIC (dalteparin) 52 & 0-6 days & $3.9 \%$ & $3.6 \%$ & $1.07(0.63-1.80)$ \\
ESSENCE (enoxaparin) 53 & 14 days & $4.6 \%$ & $6.1 \%$ & $0.75(0.55-1.02)$ \\
TIMI-11B (enoxaparin) 54 & 14 days & $5.7 \%$ & $6.9 \%$ & $0.81(0.63-1.05)$ \\
ESSENCE + TIMI-11B 55 & 14 days & $5.2 \%$ & $6.5 \%$ & $0.79(0.65-0.96) *$ \\
FRAXIS (nadroparin) 56 & 14 days & $4.9 \%$ & $4.5 \%$ & $1.08(0.72-1.62)$ \\
OVERALL & & & & $0.86(0.72-1.02)$ \\
\hline
\end{tabular}

LMWH : low molecular weight heparin; UFH: unfractionated heparin

$* \mathrm{p}=0.02$

(plus aspirin) at the very early step, before risk stratification [26]. A further advantage of this strategy is that clopidogrel pre-treatment in patients deserving of coronary angioplasty results in the $30 \%$ reduction of peri-procedure adverse events during the first 30 days following the manoeuvre [27].

In the CURE study a statistically significant $1 \%$ absolute excess in major bleeding was observed in the clopidogrel group $(\mathrm{p}=0.001)$, but there was no excess in life-threatening bleeding or intracranial haemorrhage. Authors did not include bleeds in the primary end-point because they placed more emphasis on the clinical weight of hard vascular events. It should be realised, however, that approximately 3 to $5 \%$ of patients need urgent-to-emergent cardiac surgery after hospital admission, a situation particularly at higher risk of bleeding following the aspirin-clopidogrel combination. It is recommended both to avoid clopidogrel when early surgery appears likely and to post-pone surgery (if clinically feasible) for at least 5 days after clopidogrel discontinuation.

The role of antiplatelet therapy in acute coronary syndromes is further witnessed by the reduction in major clinical outcomes obtained by using parenteral glycoprotein IIb-IIIA receptor blockers. Different agents belong to this class of drugs, with considerably different chemical composition, molecular weight, receptor affinity, specific activity and ultimately pharmacodynamic and pharmacokinetic profile. With these considerations in mind, a meta-analysis of studies addressing the role of these agents appears legitimate, yet somewhat "naïve". Small-molecule glycoprotein IIB-IIIA blockers (tirofiban, eptifibatide, lamifiban) appear to work in patients admitted to the coronary care unit (PRISM, PRISMPLUS, PURSUIT, PARAGON), whereas large chimeric antibodies such as abciximab are useless outside the catheterization laboratory (GUSTO-IV-ACS) (Table 3). The European guideline recommends the use of glycoprotein IIB-IIIA blockers in patients judged to be at "high risk" (recurrent ischemia, early post-infarction angina, troponin positivity, hemodynamic instability during the observation period, major arrhythmia, i.e. ventricular tachicardia / fibrillation, diabetes mellitus, baseline ECG changes that preclude the ST segment analysis) [26]. Following this suggestion it happens that many patients will receive both the aspirin plus clopidogrel combination and a GP IIB-IIIA blocker. However, the evidence for using this "cocktail" is not firm. Actually, the use of GP IIB-IIIA inhibitors during the previous three days was an exclusion cri- 
terion for enrolling in the CURE study. The efficacy and safety of this potent triple antiplatelet therapy has been shown in the subgroup of patients submitted to coronary angioplasty [ 28 ] but has not been addressed specifically in the larger population of all comers to the hospital with an acute coronary syndrome.

Mural coronary thrombus has also a red-tail, whereby blood coagulation should be inhibited. Traditionally, this has been achieved by the infusion of intravenous unfractionated heparin, but the evidence is weak [29].

More recently a much stronger evidence for using low molecular weight heparins has emerged [30]. The meta-analysis of thousands patients enrolled in different studies show not only that low molecular weight heparins are better than placebo in acute coronary syndromes, but also that they are at least as effective as intravenous unfractionated heparin, with the advantage of a more practical use, with no need of an intravenous infusion and no need of laboratory monitoring. Actually, for one of these agents (enoxaparin), it has been shown in two different studies (ESSENCE and TIMI-11B) $[31,32]$ the superiority of low molecular weight heparin in the triple end-point (death / myocardial infarction / refractory ischemia) reduction; when the two studies were combined [33] also the double-end point (death / myocardial infarction) was reduced by enoxaparin (Table 4). It is presently discouraged to use low molecular weight heparin in patients with glomerular filtration rate $\leq 30 \mathrm{ml} / \mathrm{min}$, for the risk of drug accumulation and the inherent difficulty to neutralize the persistent anticoagulant effect [34].

\section{The need for long-term antithrombotic treatment}

Angioscopic studies show the persistence of coronary thrombus for more than 1 month after myocardial infarction [35]. Although most coronary events occur in the first month after presentation, considerable attrition is observed thereafter, despite of the use of aspirin. Event rates appear related to the persistence of intravascular markers of ongoing thrombosis [36]. An apparent relapse of ischemic episodes is observed after heparin discontinuation [37] as well as after long-term treatment with low molecular weight heparin [38].

Therefore, it appears conceptually obvious that some form of long-term anti-thrombotic adjunct to aspirin should be advised. So far, the evidence for this long-term covering is still largely circumstantial. In the CURE study, clopidogrel addition results in event curves diverging immediately but with further separation going on continuously during the following 9 months [25]; these data have been largely confirmed in patients undergoing coronary angioplasty and 12-month combined treatment with aspirin plus clopidogrel in the CREDO study [39]. Furthermore, the combined use of warfarin (with or without aspirin) determines progressive reductions of new events over 4 years of treatment after the index episode of acute coronary syndrome (WARIS-2) [40].

\section{References}

1. Fuster V, Badimon L, Badimon JJ, Chesebro $\mathrm{JH}$. The pathogenesis of coronary artery disease and the acute coronary syndromes (1). N Engl J Med. 1992;326:242-50.

2. Fuster V, Badimon L, Badimon JJ, Chesebro $\mathrm{JH}$. The pathogenesis of coronary artery disease and the acute coronary syndromes (2). N Engl J Med. 1992;326:310-8.

3. The SYNERGY trial: Study design and rationale. American Heart Journal. 2002;143:952960.

4. Indications for fibrinolytic therapy in suspected acute myocardial infarction: collaborative overview of early mortality and major morbidity results from all randomised trials of more than 1000 patients. Fibrinolytic Therapy Trialists' (FTT) Collaborative Group. Lancet. 1994;343:311-22.

5. Boersma E, Maas AC, Deckers JW, Simoons ML. Early thrombolytic treatment in acute myocardial infarction: reappraisal of the golden hour. Lancet. 1996;348:771-5.

6. Morrison LJ, Verbeek PR, McDonald AC, Sawadsky BV, Cook DJ. Mortality and prehospital thrombolysis for acute myocardial infarction: A meta-analysis. Jama. 2000;283:2686-
92.

7. Keeley EC, Boura JA, Grines CL. Primary angioplasty versus intravenous thrombolytic therapy for acute myocardial infarction: a quantitative review of 23 randomised trials. The Lancet. 2003;361:13-20.

8. Bonnefoy E, Lapostolle F, Leizorovicz A, Steg G, McFadden E, Dubien P, Cattan S, Boullenger E, Machecourt J, Lacroute J, Cassagnes J, Dissait F, Touboul P. Primary angioplasty versus prehospital fibrinolysis in acute myocardial infarction: a randomised study. Lancet. 2002;360:825.

9. Cannon CP. Thrombolysis medication errors: benefits of bolus thrombolytic agents. Am J Cardiol. 2000;85:17C-22C.

10. Morrow DA, Antman EM, Sayah A, Schuhwerk KC, Giugliano RP, deLemos JA, Waller M, Cohen SA, Rosenberg DG, Cutler SS. Evaluation of the time saved byprehospital initiation of reteplase forST-elevation myocardial infarction; Results of the early retavasethrombolysisin myocardial infarction (ERTIMI) 19 trial. Journal of the American College of Cardiology. 2002;40:71-77.

11. Qasim A, Malpass K, O'Gorman DJ, Heber
ME. Quality improvement report: Safety and efficacy of nurse initiated thrombolysis in patients with acute myocardial infarction. BMJ. 2002;324:1328-1331.

12. Single-bolus tenecteplase compared with front-loaded alteplase in acute myocardial infarction: the ASSENT-2 double-blind randomised trial. Assessment of the Safety and Efficacy of a New Thrombolytic Investigators. Lancet. 1999;354:716-22.

13. Van de Werf F, Barron HV, Armstrong PW, Granger CB, Berioli S, Barbash G, Pehrsson K, Verheugt FW, Meyer J, Betriu A, Califf RM, Li X, Fox NL. Incidence and predictors of bleeding events after fibrinolytic therapy with fibrin-specific agents: a comparison of TNK-tPA and rt-PA. Eur Heart J. 2001;22:2253-61.

14. Fu Y, Goodman S, Chang W-C, Van de Werf F, Granger CB, Armstrong PW. Time to Treatment Influences the Impact of STSegment Resolution on One-Year Prognosis: Insights From the Assessment of the Safety and Efficacy of a New Thrombolytic (ASSENT-2) Trial. Circulation. 2001;104:2653-2659. 
15. Randomised trial of intravenous streptokinase, oral aspirin, both, or neither among 17,187 cases of suspected acute myocardial infarction: ISIS-2. ISIS-2 (Second International Study of Infarct Survival) Collaborative Group. Lancet. 1988;2:349-60.

16. The GUSTO Investigators. An International Randomized Trial Comparing Four Thrombolytic Strategies for Acute Myocardial Infarction. N Engl J Med. 1993;329:673-682.

17. Simoons M, Krzeminska-Pakula M, Alonso A, Goodman S, Kali A, Loos U, Gosset F, Louer $\mathrm{V}$, Bigonzi F. Improved reperfusion and clinical outcome with enoxaparin as an adjunct to streptokinase thrombolysis in acute myocardial infarction. The AMI-SK study. Eur Heart J. 2002;23:1282.

18. Effects of long-term, moderate-intensity oral anticoagulation in addition to aspirin in unstable angina. Journal of the American College of Cardiology. 2001;37:475-484.

19. Topol EJ. Reperfusion therapy for acute myocardial infarction with fibrinolytic therapy or combination reduced fibrinolytic therapy and platelet glycoprotein IIb/IIIa inhibition: the GUSTO V randomised trial. The Lancet. 2001;357:1905-1914.

20. Brener SJ, Zeymer U, Adgey AAJ, Vrobel TR, Ellis SG, Neuhaus K-L, Juran N, Ivanc TB, Ohman EM, Strony J. Eptifibatide and lowdose tissue plasminogen activator in acute myocardial infarction; The integrilin and lowdose thrombolysis in acute myocardial infarction (INTRO AMI) trial. Journal of the American College of Cardiology. 2002;39:377-386.

21. Van de Werf F, Ardissino D, Betriu A, Cokkinos DW, Falk E, Fox KAA, Julian D, Lengyel M, Neumann F-J, Ruzyllo W, Thygesen C, Underwood RS, Vahanian A, Verheugt FWA, Wijns W. Management of acute myocardial infarction in patients presenting with ST-segment elevation. The Task Force on the Management of Acute Myocardial Infarction of the European Society of Cardiology. European Heart Journal. 2003;24:28-66.

22. Antman EM, Cohen M, Bernink PJ, McCabe $\mathrm{CH}$, Horacek T, Papuchis G, Mautner B, Corbalan R, Radley D, Braunwald E. The TIMI risk score for unstable angina/non-ST elevation MI: A method for prognostication and therapeutic decision making. Jama. 2000;284:835-42.

23. Boersma E, Pieper KS, Steyerberg EW, Wilcox RG, Chang W-C, Lee KL, Akkerhuis KM, Harrington RA, Deckers JW, Armstrong PW, Lincoff AM, Califf RM, Topol EJ, Simoons ML. Predictors of Outcome in Patients With Acute Coronary Syndromes Without Persistent ST-Segment Elevation : Results From an International Trial of 9461 Patients. Circulation. 2000;101:2557-2567.

24. Al Suwaidi J, Reddan DN, Williams K, Pieper KS, Harrington RA, Califf RM, Granger CB, Ohman EM, Holmes DR, Jr, for the GUSTOIIb G-I, PURSUIT, and PARAGON-A Investigators, . Prognostic Implications of Abnormalities in Renal Function in Patients With Acute Coronary Syndromes. Circulation.
2002; 106:974-980

25. The Clopidogrel in Unstable Angina to Prevent Recurrent Events Trial Investigators. Effects of Clopidogrel in Addition to Aspirin in Patients with Acute Coronary Syndromes without ST-Segment Elevation. N Engl J Med. 2001;345:494-502.

26. Bertrand ME, Simoons ML, Fox KA, Wallentin LC, Hamm CW, McFadden E, De Feyter PJ, Specchia G, Ruzyllo W. Management of acute coronary syndromes in patients presenting without persistent ST-segment elevation. Eur Heart J. 2002;23:1809-40.

27. Mehta SR, Yusuf S, Peters RJ, Bertrand ME, Lewis BS, Natarajan MK, Malmberg K, Rupprecht H, Zhao F, Chrolavicius S, Copland I, Fox KA. Effects of pretreatment with clopidogrel and aspirin followed by long-term therapy in patients undergoing percutaneous coronary intervention: the PCI-CURE study. Lancet. 2001;358:527-33.

28. Topol EJ, Moliterno DJ, Herrmann HC, Powers ER, Grines CL, Cohen DJ, Cohen EA, Bertrand M, Neumann FJ, Stone GW, DiBattiste PM, Demopoulos L. Comparison of two platelet glycoprotein IIb/IIIa inhibitors, tirofiban and abciximab, for the prevention of ischemic events with percutaneous coronary revascularization. $\mathrm{N}$ Engl J Med. 2001;344:1888-94.

29. Oler A WM, Oler J, Grady D. Adding heparin to aspirin reduces the incidence of myocardial infarction and death in patients with unstable angina: a meta-analysis. JAMA. 1996;276:811-815

30. Eikelboom JW, Anand SS, Malmberg K, Weitz JI, Ginsberg JS, Yusuf S. Unfractionated heparin and low-molecular-weight heparin in acute coronary syndrome without ST elevation: a meta-analysis. Lancet. 2000;355:193642.

31. Cohen M, Demers C, Gurfinkel EP, Turpie AGG, Fromell GJ, Goodman S, Langer A, Califf RM, Fox KAA, Premmereur J, Bigonzi F, Stephens J, Weatherley B, The Efficacy and Safety of Subcutaneous Enoxaparin in Non-QWave Coronary Events Study Group. A Comparison of Low-Molecular-Weight Heparin with Unfractionated Heparin for Unstable Coronary Artery Disease. N Engl J Med. 1997;337:447-452.

32. Antman EM, McCabe CH, Gurfinkel EP, Turpie AGG, Bernink PJLM, Salein D, Bayes de Luna A, Fox K, Lablanche J-M, Radley D, Premmereur J, Braunwald E. Enoxaparin Prevents Death and Cardiac Ischemic Events in Unstable Angina/Non-Q-Wave Myocardial Infarction : Results of the Thrombolysis In Myocardial Infarction (TIMI) 11B Trial. Circulation. 1999;100:1593-1601.

33. Antman EM, Cohen M, Radley D, McCabe C, Rush J, Premmereur J, Braunwald E. Assessment of the Treatment Effect of Enoxaparin for Unstable Angina/Non-Q-Wave Myocardial Infarction : TIMI 11B-ESSENCE Meta-Analysis. Circulation. 1999;100:16021608.

34. Nagge J, Crowther M, Hirsh J. Is impaired renal function a contraindication to the use of low-molecular-weight heparin? Arch Intern
Med. 2002;162:2605-9

35. Van Belle E, Lablanche J-M, Bauters C Renaud N, McFadden EP, Bertrand ME. Coronary Angioscopic Findings in the InfarctRelated Vessel Within 1 Month of Acute Myocardial Infarction : Natural History and the Effect of Thrombolysis. Circulation. 1998;97:26-33.

36. Merlini PA, Bauer KA, Oltrona L, Ardissino D, Cattaneo M, Belli C, Mannucci PM, Rosenberg RD. Persistent activation of coagulation mechanism in unstable angina and myocardial infarction. Circulation. 1994;90:61-8.

37. Theroux P, Waters D, Lam J, Juneau M, McCans J. Reactivation of unstable angina after the discontinuation of heparin. N Engl J Med. 1992;327:141-5.

38. Long-term low-molecular-mass heparin in unstable coronary-artery disease: FRISC II prospective randomised multicentre study. FRagmin and Fast Revascularisation during InStability in Coronary artery disease. Investigators. Lancet. 1999;354:701-7.

39. Steinhubl SR, Berger PB, Mann JT, 3rd, Fry ET, DeLago A, Wilmer C, Topol EJ. Early and sustained dual oral antiplatelet therapy following percutaneous coronary intervention: a randomized controlled trial. Jama. 2002;288:2411-20.

40. Hurlen M, Abdelnoor M, Smith P, Erikssen J, Arnesen H. Warfarin, Aspirin, or Both after Myocardial Infarction. $\mathrm{N}$ Engl $\mathrm{J}$ Med. 2002;347:969-974.

41. Montalescot G, Barragan P, Wittenberg O, Ecollan P, Elhadad S, Villain P, Boulenc J-M, Morice M-C, Maillard L, Pansieri M, Choussat R, Pinton $\mathrm{P}$, the ADMIRAL Investigators. Platelet Glycoprotein IIb/IIIa Inhibition with Coronary Stenting for Acute Myocardial Infarction. $\mathrm{N}$ Engl $\mathrm{J}$ Med. 2001;344:1895-1903.

42. Brener SJ, Barr LA, Burchenal JEB, Katz S, George BS, Jones AA, Cohen ED, Gainey PC, White HJ, Cheek HB, Moses JW, Moliterno DJ, Effron MB, Topol EJ. Randomized, Placebo-Controlled Trial of Platelet Glycoprotein IIb/IIIa Blockade With Primary Angioplasty for Acute Myocardial Infarction. Circulation. 1998;98:734-741.

43. Neumann FJ, Kastrati A, Schmitt C, Blasini R, Hadamitzky M, Mehilli J, Gawaz M, Schleef M, Seyfarth M, Dirschinger J, Schomig A. Effect of glycoprotein IIb/IIIa receptor blockade with abciximab on clinical and angiographic restenosis rate after the placement of coronary stents following acute myocardial infarction. J Am Coll Cardiol. 2000;35:91521.

44. Stone GW, Grines CL, Cox DA, Garcia E, Tcheng JE, Griffin JJ, Guagliumi G, Stuckey T, Turco M, Carroll JD, Rutherford BD Lansky AJ, the Controlled Abciximab and Device Investigation to Lower Late Angioplasty Complications (CADILLAC) Investigators. Comparison of Angioplasty with Stenting, with or without Abciximab, in Acute Myocardial Infarction. $\mathrm{N}$ Engl $\mathrm{J}$ Med. 2002;346:957-966.

45. Boersma E, Harrington RA, Moliterno DJ, 
White H, Theroux P, Van de Werf F, de Torbal A, Armstrong PW, Wallentin LC, Wilcox RG. Platelet glycoprotein IIb/IIIa inhibitors in acute coronary syndromes: a meta-analysis of all major randomised clinical trials. The Lancet. 2002;359:189-198.

46. The Platelet Receptor Inhibition in Ischemic Syndrome Management (PRISM) Study Investigators. A Comparison of Aspirin plus Tirofiban with Aspirin plus Heparin for Unstable Angina. N Engl J Med. 1998;338:1498-1505.

47. The Platelet Receptor Inhibition in Ischemic Syndrome Management in Patients Limited by Unstable Signs and Symptoms (PRISMPLUS) Study Investigators. Inhibition of the Platelet Glycoprotein IIb/IIIa Receptor with Tirofiban in Unstable Angina and Non-QWave Myocardial Infarction. N Engl J Med.
1998;338:1488-1497.

48. International, Randomized, Controlled Trial of Lamifiban (a Platelet Glycoprotein IIb/IIIa Inhibitor), Heparin, or Both in Unstable Angina. Circulation. 1998;97:2386-2395.

49. The PURSUIT Trial Investigators. Inhibition of Platelet Glycoprotein IIb/IIIa with Eptifibatide in Patients with Acute Coronary Syndromes. N Engl J Med. 1998;339:436-443.

50. Randomized, Placebo-Controlled Trial of Titrated Intravenous Lamifiban for Acute Coronary Syndromes. Circulation. 2002;105:316-321.

51. Simoons ML. Effect of glycoprotein IIb/IIIa receptor blocker abciximab on outcome in patients with acute coronary syndromes without early coronary revascularisation: the GUSTO IV-ACS randomised trial. The Lancet. 2001;357:1915-1924.
52. Klein W, Buchwald A, Hillis SE, Monrad S, Sanz G, Turpie AG, van der Meer J, Olaisson $\mathrm{E}$, Undeland S, Ludwig K. Comparison of low-molecular-weight heparin with unfractionated heparin acutely and with placebo for 6 weeks in the management of unstable coronary artery disease. Fragmin in unstable coronary artery disease study (FRIC). Circulation. 1997;96:61-8.

53. Comparison of two treatment durations (6 days and 14 days) of a low molecular weight heparin with a 6-day treatment of unfractionated heparin in the initial management of unstable angina or non-Q wave myocardial infarction: FRAX.I.S. (FRAxiparine in Ischaemic Syndrome). Eur Heart J. 1999;20:1553-62. 